\title{
Poradnik domowy Anny Margarethy Justiny Lindheimer
}

Ewa Jurczyk 
KAPTS Seria VI 2000

\section{Ewa Jurczyk}

\section{Poradnik domowy}

\section{Anny Margarethy Justiny Lindheimer}

nna Margaretha Justina Lindheimerin sławę zawdzięcza nie swojej książce kucharskiej,
lecz faktowi, że była babką Johanna Wolfganga Goethego.

Kiedy w roku 1893 zmarł hrabia Ludwig von Paar, zgodnie z jego ostatnią wolą zlicytowano jego zbiór rękopisów. Archiwum Goethego i Schillera w Weimarze, zainteresowane zgromadzeniem wszystkich rękopisów związanych z wielkimi poetami, zdołało w 1893 roku zakupić do swoich zbiorów książkę kucharską babki Goethego.

Życie Anny Lindheimer (1711-1783) nie wyróżnia się niczym nadzwyczajnym. Wychowana $\mathrm{w}$ typowym domu mieszczańskim, od dziecka przygotowywana była do roli żony i matki; pod kierunkiem wcześnie owdowiałej matki uczyła się podstaw czytania, rachunków i pisania, a przede wszystkim prowadzenia gospodarstwa domowego. Jako piętnastolatka została wydana za starszego o 18 lat prawnika Johanna Wolfganga Textora (1693-1771), urodziła ośmioro i wychowała sześcioro dzieci, prowadziła gospodarstwo swojego męża. Po przeprowadzce $z$ prowincjonalnego Wetzlaru do Frankfurtu musiała, jako jeszcze bardzo młoda mężatka, prowadzić dom otwarty, jako że Textorowie należeli do najznamienitszych rodzin w mieście. Po śmierci męża mieszkała dalej we Frankfurcie, w każdą niedzielę rozpieszczając przygotowanymi przez siebie potrawami swojego wnuka, Johanna Wolfganga Goethego. Musiały być to dobre dania, skoro tak mocno zapadły w pamięć poety, że poświęcił im kilka fragmentów wspomnień $Z m y$ slenie i prawda.

Edukacji w zakresie prowadzenia gospodarstwa domowego służyć miał mały, oprawiony w brązową skórę zeszycik, który Anna Lindheimer dostała najprawdopodobniej w wieku 13 lat jako prezent konfirmacyjny. Autorką przypuszczalnie jest kobieta z jej najbliższej rodziny, ale na pewno nie jest nią zbytnio zajęta sprawami rodziny matka. Nieznana autorka zapisała dla Anny Margarethy 107 stron. Zamężna już Anna dopisała następne, a na pozosta- 
łych stronach zapisków dokonywał jej mąż. Zgodnie bowiem z tradycją, w której została także wychowana Anna Lindheimer, żona należała do domowników, nad którymi władzę sprawował pan domu. W dowód podporządkowania się woli męża i szacunku dla niego przekazała mu do uzupełnienia zapiski w brązowym zeszyciku. Johann Wolfgang Textor prowadził zapiski w tradycyjnym stylu „poradnika domowego" . Tak więc zeszycik, pomyślany pierwotnie jako książka kucharska, stał się z czasem notatnikiem domowym. Dlatego na później zapisanych stronach znajdujemy notatki dotyczące otrzymanych prezentów, porady praktyczne dla domowników, na przykład ,jak sklejać rozbite szklanki”, (141) ,jak zrobić ładny czerwony atrament" (45), ,jak zmieniać kolory kwiatów" (172), oraz porady dla zdrowia i urody.

Brązowy zeszycik ofiarowany Annie Lindheimer był kompendium wiedzy i doświadczeń starszej krewnej i zarazem drogowskazem dla przyszłej pani domu i kucharki. Autorka spisała w nim najważniejszą wiedzę zawartą w książkach kucharskich, wydawanych zarówno z myślą o mieszczańskiej pani domu ${ }^{2}$, jak i o kucharzach gotujących dla osób z wyższych sfer. Jednak przepisy zawarte w zeszyciku nie są po prostu przepisane. Są to przepisy wypróbowane, udoskonalone, a przede wszystkim dostosowane do możliwości finansowych mieszczan. Nie są to więc porady, jak przygotować wykwintne potrawy, charakterstyczne dla stołów szlacheckich - wyszukane pasztety, pieczyste czy torty - lecz raczej rady, jak przystosować szlacheckie potrawy do możliwości mieszczańskiej kieszeni. Nie znaczy to jednak, że niemiecki stół mieszczański był biedny. Chodziło o to, aby jedzenie było solidne i aby nic się nie zmarnowało, a jednocześnie dania przygotowane i podane były bardzo kolorowo i efektownie. W zeszyciku dla Anny Lindheimer znajdujemy więc praktyczne wskazówki, jak urządzać uczty nie tylko dla podniebienia, lecz także dla oka. Dlatego na samym początku zapisano sposoby wykonania modnych wówczas woskowych atrap różnych potraw. Owe ozdoby stołu, odlewane $z$ mieszaniny wosku, terpentyny i barwników, to przede wszystkim produkty spożywcze, na przykład kiełbasy, raki, rzepy, jajka, kurczaki, śledzie, szparagi i orzechy.

W poradach dla panny $z$ dobrego domu znajdujemy kilka prawidłowości:

- Proponowane potrawy przyrządzone są z produktów tanich (baranina, podroby), ale dobrego gatunku (biała mąka pszenna, cukier z Wysp Kanaryjskich);

- Proponowane przepisy sa przepisami realnymi, możliwymi do przygotowywania z produktów ogólnie dostępnych na rynku;

- W zestawie potraw dominują potrawy słodkie;

- W kuchni mieszczańskiej używano dużej ilości ostrych i aromatycznych przypraw, i to zarówno do potraw słodkich, jak i słonych. Były to: imbir, goździki, anyżek, gałka i kwiat muszkatołowy, kolendra, szafran, cynamon i pieprz;

\footnotetext{
' Zob. A. M. J. Lindheimerin, Das Kochbuch von Goethes Großmutter, hsgb E. Beck, Leipzig 1980, s. 21. Numeracja w tekście w nawiasach dotyczy tego wydania.

${ }^{2}$ Por. M. Rumpolt, Ein new Kochbuch, Frankfurt am Main 1581, reprint 1976; E. M. Rosalia, Freywillig aufgesprungener Granat-Apfel, Leipzig 1709, reprint 1978; C. Hagger, Neues Salzburgisches Koch-Buch, Augsburg 1719, reprint 1977.
} 
- Większość przepisów zakłada posiadanie instynktu lub znajomość podstawowych zasad gotowania i pieczenia. Oznacza to, że nie zawsze podawane są dokładne proporcje. Autorka radzi na przykład: „weź tyle słodkiego masła, co jajek” (40) lub „weź mąki tyle, ile uważasz za potrzebne” (41); karpia gotowano „tyle, co jajka na twardo” (68).

Anna Lindheimer musiała także nauczyć się, że:

- Rodzynki, suszone winogrona i migdały kupuje się w większych ilościach, na zapas, aby uniezależnić się od wahań cen na rynku;

- Szanująca się pani domu w przydomowym ogródku hoduje zioła, kwiaty i owoce popularne w tych szerokościach geograficznych. (Jak wspomina Goethe w pierwszej księdze Dichtung und Wahrheit, babcia przynosiła z ogródka majeranek, fenkuły, pietruszkę, cebulę, rozmaryn, ogórki, sałatę, szpinak, a także pączki róż do przygotowania cukru różanego ${ }^{3}$ );

— Stół i potrawy ozdabia się dodatkowo kwiatami.

$\mathrm{Z}$ porad spisanych dla Anny Lindheimer wynika, że praca w kuchni w tych czasach była bardzo ciężka i monotonna. Chociażby samo przygotowanie cukru do potrawy: $z$ ogromnej bryły cukru należało odłamać odpowiedni kawałek, a następnie przez dłuższy czas rozdrabniać, rozbijać, ucierać itp. W wypadku ciast rozdrabnianie cukru trwało często ponad godzinę. A w domu Textorów ciasta cieszyły się dużym powodzeniem. Wypiekano makaroniki muszkatołowe na bazie migdałów (25), słodkie chleby z migdałami, cynamonem, goździkami i skórką cytrynową (27), chleb cytrynowy (28), ciasteczka winne (40), śmietankowe i cynamonowe (30), ciasteczka kruche przekręcane przez maszynkę (22). Zużywano przy tym nie tylko duże ilości migdałów i cukru, lecz i jajek. Aby przygotować ciasteczka cưkrowe, należało przez godzinę ucierać 11-12 jajek, dodając stopniowo cukier i wodę różaną. Masę należało wylać na blaszkę, ustawić na parze, po ścięciu się pokroić w kawałki i dopiero upiec. Podobnie pracochłonne było przyrządzenie ciasta biszkoptowego. Najpierw należało ubić 10 białek, potem 10 żółtek, połączyć obydwie masy i dalej ubijać, lekko podgrzać i dopiero potem dodać cukier i mąkę (134).

W zeszyciku Anny Lindheimer uderza przewaga potraw słodkich, niekoniecznie ciast. Jest to zjawisko typowe dla tego okresu, bo także w książkach kucharskich, dostępnych na rynku, obok potraw z mięsa i ryb zajmują najwięcej miejsca potrawy słodkie. A umiejętność przygotowywania słodkich wypieków, słodkich deserów i wszelkiego rodzaju łakoci przysparzało każdej pani domu najwięcej sympatii domowników i gości. Goethe wspominając dzieciństwo i babcię pisał, że dzień Nowego Roku w domu dziadka był dla nich, dzieci, szczególny z powodu „tortów, biszkopcików, marcepanów i słodkiego wina” (Dichtung und Wahrheit, ks. $\left.3^{4}\right)$.

\footnotetext{
${ }^{3}$ Zob. J. W. v. Goethe, Aus meiner Leben. Dichtung und Wahrheit I, 1, w: idem, Werke [Hamburger Ausgabe], t. IX: Autobiographische Schriften I, opr. L. Blumenthal, koment. E. Trunz, München 1989, s. 38-39, 659-660 (przypisy).

${ }^{4}$ Zob. ibid., s. 82-83; Nowy Rok u dziadków jest tematem zachowanego młodzieńczego wiersza Goethego (zob. ibid., s. 672, przypis do s. 82).
} 
Potrawy słodkie w zeszyciku Anny Lindheimer to: ciasteczka, pierniki, marcepan, desery, łakocie z migdałów, słodkie zaprawy i syropy. A ponieważ słodycze zawsze dodatkowo barwiono „fioletowym sokiem" lub "czerwonym sokiem" i wlewano lub wciskano w rozmaite formy, była to dla domowników uczta szczególnego rodzaju.

Specyficznym rodzajem wypieków były pierniki. W książce dla Anny znajdujemy kilka przepisów na pierniki oraz uwagę, że najsłynniejsze wypiekane są w Norymberdze, i że nikomu dotychczas nie udało się ich w domu upiec tak, aby smakowały jak oryginalne. Oprócz głównych składników - miodu, jajek, cukru i mąki — dodawano do pierników przypraw używanych do dziś - galkę muszkatołową, imbir, skórkę z cytryny, czasami też wino. Dla Anny Lindheimer spisano również przepis na oszczędne „białe” pierniki, pieczone na opłatkach (20).

Do ulubionych łakoci przygotowywanych w domu należał marcepan, którego gospodyni domowa używała nie tylko do przygotowania ciast, lecz także do przyozdabiania słodkich potraw lub sporządzania cukierków. Dawny przepis na wykonanie marcepanu różni się nieco od dzisiejszego. W czasach Goethego używano zmielonych migdałów, miałko utartego cukru, wody różanej i mąki ziemniaczanej (24).

Do prawie wszystkich potraw słodkich dodawano wody różanej (nawet zbyt gęste ciasto radzono nią rozrzedzać), którą szanująca się pani domu przygotowywała z róż wyhodowanych wlasnoręcznie w ogrodzie. Annie Lindheimer poleca się używać do tego celu róż szkarłatnych lub bladoróżowych. O aromatycznej Centifolii, polecanej do wszelkiego rodzaju zapraw z róży, nie wspomina.

Desery ogólnie można podzielić na bardzo pracochłonne i szybkie. Przeważają desery szybkie, na przykład migdały siekane $\mathrm{z}$ cukrem, wymieszane $\mathrm{z}$ wodą różaną i jajkami, a następnie zapiekane na opłatkach lub waflach (53), jabłka zapiekane z migdałami i rodzynkami (75), rodzynki moczone w winie i zapiekane $z$ białym chlebem (76), śliwki lub figi nadziewane migdałem i zapiekane w cieście naleśnikowym (80) i tradycyjne słodkie niemieckie śniadanie - miąższ chleba moczony w mleku i smażony z cukrem.

Niektóre desery musiały „dojrzewać” dłuższy czas, choćby jabłka macerowane w winie i zapiekane w cieście naleśnikowym. Inne znowu, jak na przykład pianka z białek, wymagały ogromnego nakładu pracy. Taką pianę należało najpierw około godziny ubijać, potem formować z niej kluseczki, gotować je w mleku, a następnie chłodzić w piwnicy (42). Bardzo często do sporządzania deserów używano migdałów. Siekane mieszano z ubitymi białkami i zapiekano na opłatkach, lub mieszano z cukrem, wodą różaną, jajkami i mąką i zapiekano na różne sposoby $(62,63)$.

Do wyrobu słodkich potraw używane bardzo chętnie, zapomnianego już dzisiaj trochę, owocu pigwy. Jego aromatyczny miąższ używany był do sporządzania wielu deserów i łakoci. Pani domu często podawała syropy przyrządzane z jabłek i owocu pigwy $(11,12,13)$, owocu pigwy i cytryn (16) lub malin i czereśni (26). Był to jednak inny syrop niż nasz współczesny - nie był to napój, lecz galaretka. Owoce gotowano z cukrem tak długo, dopóki kropla 
wywaru wylana na talerz nie ścinała się. Tak wygotowane owoce przecedzano przez ściereczkę i wylewano do zastygnięcia do foremek. Podano także sposób na sporządzanie różnego rodzaju galaretek, w których zamiast żelatyny używano moczonego dłuższy czas pęcherza pławnego ryb (104).

Także wśród zapraw dominują zaprawy słodkie. Często kandyzowano owoce - cytryny i pomarańcze, przygotowywano czereśnie, porzeczki i cytryny w zalewie cukrowej (21). W tym celu należało owoce starannie przebrać i gotować kilka dni w wodzie z cukrem lub soku własnym, a następnie owoce zalać syropem $\mathrm{z}$ cukru. W wypadku cytryn syrop należało przygotować z cukru i wody różanej (54). Często aromatyzowano miód poprzez zagotowanie go $z$ dodatkiem kwiatu czarnego bzu (50). Przyrządzano także cukier różany i cukier pomarańczowy (112). Obydwa cukry uzyskiwano poprzez gotowanie kwiatu róży lub pomarańczy w roztworze cukru.

Największego nakładu pracy wymagały słodkie zaprawy z orzechów. Jeden z przepisów poleca moczyć orzechy przez 12 dni w wodzie (w piwnicy), potem gotować je do miękkości, dodać cynamon i goździki, przez jakiś czas gotować w roztworze cukru, wyjąć, znowu gotować, wyjąć, a następnie zalać syropem (58). Jeszcze więcej pracy wymagało przygotowanie orzechów włoskich. Te należało moczyć w wodzie przez 14 dni, a wodę codziennie zmieniać. Po tym czasie orzechy należało ponakłuwać, a w nakłucia wkładać paseczki kandyzowanej skórki z cytryny, goździki lub kawałeczki cynamonu. Takk spreparowane orzechy smażono kilka razy w cukrze (129).

Do zapraw przygotowywanych na cały rok należało także przygotowane sposobem domowym mleko w proszku. Robiono je z koziego mleka, gotowanego tak długo, aż utworzy się bryła, którą następnie należało rozbić i dokładnie rozmieszać. Powstały proszek dodawano do herbaty, która ,jest od tego tłusta, można też pić z kawą" (136).

W zeszycie Anny Lindheimer znalazło się też kilka przepisów na przygotowanie ciekawych trunków. Często były to pomysły na „uszlachetnienie” napoju alkoholowego sokiem $z$ owoców - na przykład winiaku dodatkiem soku z czereśni (60). Znajdujemy tu także przepis na wino z rodzynków (167) lub na sok z czereśni na bazie wina (29). Dla uzyskania tego ostatniego należało czereśnie zmiażdżyć w moździerzu, zalać winem, doprawić cukrem, cynamonem i goździkami.

Wśród przepisów na napoje umieszczono także kilka na napoje bezalkoholowe, na przykład sok z malin gotowany przez 24 godziny (47) lub sok z owocu pigwy przygotowywany bez dodatku cukru (46).

Stosunkowo mało jest przepisów na przyrządzanie jarzyn (jedynie szpinak i sałata jako jarzyna do obiadu). Zakłada się, że najprawdopodobniej przepisy te były młodej dziewczynie znane ${ }^{5}$. Wśród tych nielicznych przepisów zwraca uwagę przepis na groszek konserwowany „tak, aby był zielony przez całą zimę". Zaleca się przechowywanie go w soli; przed ugotowaniem należało go kilka razy wypłukać (127). W oryginalny sposób przyrządzano także ogórki — po usmażeniu zalewano je tłustym rosołem $\mathrm{z}$ baraniny (65).

\footnotetext{
${ }^{5}$ Zob. A. M. J. Lindheimerin, op. cit., s.17.
} 
W kuchni Textorów brakuje zupełnie potraw z grzybów. Jedyny przepis dotyczy pieczarek. Zaleca się je najpierw wygotować w wodzie z octem, wodę wylać, dopiero potem przyrządzić grzyby (111), bo jedynie w taki sposób usuwa się z nich substancje trujące. Najpewniejsze pod względem zdrowotnym są pieczarki konserwowane w occie. Młodej gospodyni radzi się także, jak wkomponować potrawy z pieczarek w menu: jeżeli pieczarki podawane są na obiad, to potrawa przed nimi lub po nich powinna być kwaśna, a jako napój należy podać czerwone wino.

Potrawy mięsne przygotowywane były przeważnie $z$ mięs tanich (baranina, drób) i podrobów (nerki, płucka), co powodowało, że takie obiady nie musiały być kosztowne. Dodatkowo Anna Lindheimer mogła znaleźć wiele przepisów na potrawy mięsne z resztek (paszteciki, klopsiki). Dla przygotowania potraw mięsnych stosuje się te same przyprawy i zioła, co dla potraw słodkich, z tą jedynie różnicą, że zamiast cukru dodaje się soli. Baranina na przykład przed przyrządzeniem była przez godzinę macerowana w soli, goździkach i pieprzu, smażona natomiast z cytryną, cebulą i octem (61). Dziczyznę przyrządzano z pieprzem, goździkami, mąką, cebulą i jałowcem (62). Z dziczyzny gotowano także rosół — sprawione mięso gotowano z octem, pieprzem, gałką muszkatołową i cytryną (63). Na cielęcinę podano dwa przepisy: $w$ jednym smaży się mięso $z$ masłem, pieprzem, imbirem, gałką muszkatołową i cebulą (64); w innej wersji cielęcinę należy podsmażyć, potem dusić z gałką, cytryną i rosołem (69).

Do macerowania mięsa zaleca się przygotowanie zalewy z jałowca, kminku, octu i soli; w takiej zalewie mięso należało moczyć przez całą noc. (100)

W domu Textorów zjadano także dużo kotletów siekanych, sporządzonych z resztek mięs i podrobów. Pasztety sporządzano z mięsa wołowego siekanego z octem i solą; do masy dodawano szpik, bułeczki moczone w rosole, cytrynę i gałkę muszkatołową $(104,110)$.

Podrobów używano nie tylko do sporządzenia klopsików lub pasztetów. Przepisy zawarte w książce Anny Lindheimer to także propozycje lekkich, szybkich przekąsek, na przykład drobno pokrojone nerki przyprawione gałką muszkatołową, wymieszane z jajkami i zapiekane na chlebie (60), albo kawałki płucek cielęcych zapiekanych w cieście naleśnikowym (66).

W przepisach z drobiu uderza, że ptaków nie przygotowywano w całości, lecz w częściach. Kurę dzielono na cztery części i przez cztery godziny duszono w maśle, dodając przyprawy, cebulę, pietruszkę, szczypiorek i majeranek; następnie dodawano rosół z mięsa, cytrynę, ocet i jajka (73) i gotowano dalej. Kurę pokrojoną na małe kawałki można było od razu gotować w rosole $\mathrm{z}$ mięsa, dodając do niego szczypiorek, pietruszkę, majeranek i masło (73). Jest także przepis na gołębie; sprawione dzielono na cztery części i gotowano w rosole doprawionym octem, solą, pieprzem, imbirem i goździkami; po jakimś czasie dodawano do rosołu posiekaną wątrobę, serce i cebulę, i całość przyprawiano majerankiem i pietruszką (64). W dalszej części poradnika znajdujemy informację, żeby drób przed zabiciem napoić łyżką octu winnego, bo wtedy mięso będzie delikatniejsze (115).

W domu Textorów spożywało się także duże ilości ryb i raków. Ryby przede wszystkim gotowano i podawano $\mathrm{z}$ sosem przyrządzonym $\mathrm{z}$ zagęszczonego rosołu, w którym ryba była 
gotowana. Szczupaka gotowano najpierw w solonej wodzie, potem w rosole $\mathrm{z}$ mięsa $\mathrm{z}$ dodatkiem gałki muszkatołowej, imbiru, pieprzu i cebuli; po ugotowaniu ryby rosół zagęszczany był jajkiem i octem (66). Karpie gotowano w winie $\mathrm{z}$ dodatkiem octu i soli. Sos do ryby przygotowywano z zasmażki z mąki i czerstwego chleba (67). Łososia gotowano w winie $z$ octem (68), węgorza gotowano, a następnie smażono na maśle, dodając szałwi i soli (71); pstrągi gotowano z pieprzem, imbirem i odrobiną octu, potem doprawiono jajkiem i masłem (81). Dla ugotowania białej ryby przygotowywano rosół na zasmażce z białego smalcu, cebuli, łyżki mąki, winnego octu, pieprzu, soli i imbiru (81).

Oprócz potraw z ryb przyrządzano też potrawy z raków, często $w$ formie przystawki, na przykład raki zapiekane na chlebie oraz raki zapiekane w skorupkach. Tę ostatnią potrawę przygotowywano w nieco makabryczny sposób, ponieważ należało rozciąć żywe raki, wyciąć najlepsze mięso, przyprawić pieprzem i solą, dodać masło, włożyć w skorupki i zapiec (124). Poleca się także przygotowanie zupy $z$ raków. W tym wypadku raki gotowane były w rosole $\mathrm{z}$ mięsa ze śmietaną, zupę podawano z kulkami z mięsa (78).

Rosoły podawano z kluseczkami przygotowanymi z masła, jajek, przypraw i dowolnej zieleniny oraz mąki $(80,81,84)$. Jeżeli do rosołu podawano kluseczki, wtedy nie należało solić rosołu.

W książce Anny Lindheimer nie pojawiają się przepisy na przygotowanie potraw z ziemniaków, mimo że w książkach kucharskich z tego okresu nie brak takich przepisów; są to jednak jedynie propozycje sałatek. Brak przepisów na ziemniaki w zeszyciku Anny Lindheimer należałoby wiązać $\mathrm{z}$ faktem, że Textorowie mieszkali w regionie znanym z zamiłowania do wszelkiego rodzaju klusek. W ich domu jadano dlatego kluski na słono i słodko, w rosole i jako samodzielną potrawę. Kluski na słodko sporządzano z jajek, nieodłącznej wody różanej, cukru i cynamonu, a smażono je w smalcu. Kluski na słono sporządzano na przykład z białego chleba z przyprawami i gotowano w rosole (72) albo ze szpiku z szafranem (74), albo $z$ wolowiny i boczku (77).

Rzadką alternatywą dla klusek był ryż, przyrządzany w bardzo pracochłonny sposób. Ryż należało przygotować na dzień przed podaniem do obiadu. Najpierw zalewało się go gorącą wodą, żeby napęczniał, potem gotowało się go w mleku, a następnie owijało kilkoma warstwami ciepłych tkanin i zostawiało na całą noc, aby jeszcze bardziej spęczniał (181).

W dalszej części zeszytu Anny Lindheimer znajdują się spisane ręką jej męża porady dla zdrowia. Są to przepisy wywodzące się zarówno $z$ tradycji ziołolecznictwa domowego, jak i z doświadczeń współczesnych lekarzy, które także bazowały na tradycji ziołoleczniczej. W poradach zarówno jednych, jak i drugich paleta środków sięgała od aloesu do korzenia ostryżu plamistego, od lisich płucek poprzez oczy raka do dżdżownic. Wszystkie składniki lekarstw można było kupić w aptece, dlatego oszczędny mieszczanin dokładnie spisywał składniki $z$ recept wystawianych przez lekarza, aby potem $\mathrm{w}$ razie takiej samej choroby u innego domownika nie płacić już za wizytę lekarską, lecz móc lekarstwo sporządzić samemu.

Porady zdrowotne zajmują równie ważne miejsce, jak i same przepisy kulinarne. Bardzo często spotykaną dolegliwością były wszelkiego rodzaju niedyspozycje żołądkowe, co było zrozumiałe w wypadku tak ciężkiej kuchni. Dlatego znajdujemy tu przepisy na krople 
żołądkowe na bazie gałki muszkatołowej, kardamonu i cukru (148), na proszek żołądkowy o składzie podobnym do składu dzisiejszej Melisany. Proszek ten miał wszechstronne działanie, bo „oczyszcza flegmę ze złej cholery, także krew; przepędza migreny, melancholię, odświeża umysł, wzmacnia serce" (118). Zapisano także środek na wzmocnienie w chorobie. Należało posiekać mięso kapłona i cielęcinę, dodać gałki muszkatołowej i gotować pod przykryciem w kąpieli wodnej; powstały wywar odlać przez ściereczkę i pozostawić do powstania galaretki. Owa galaretka miala uzdrawiające właściwości, ponieważ zalecano dodawać trzy łyżki do rosołu rekonwalescenta (121). Także w przypadku innych dolegliwości znano odpowiedni środek zaradczy. Kiedy „dziąsła odpadają od zębów”, pomaga mieszanina krwawnika, liścia poziomki, szałwi i ałunu (108); zajady na wargach traktuje się maścią zrobioną $z$ miodu zmieszanego $z$ suszonym sproszkowanym pięciornikiem (109); na oparzenia nakłada się sok z cebuli, po zastosowaniu którego nie powstawały blizny (145).

Nieco dziwny w tym dosyć logicznym i przekonującym zestawie porad jest sposób na usuwanie brodawek. Zaleca się wziąć tyle źdźbeł siana, ile jest brodawek, dotkną́ nimi brodawek, a następnie źdźbła zakopać pod gnojem, żeby zgniły, bo wraz z nimi zgnija brodawki (140).

Obok porad dotyczących usuwania dolegliwości, Wolfgang Textor spisał dla żony także porady dotyczące pielęgnacji ciała.

Znajdujemy tu domowy przepis na zrobienie mydła — sporządzano je z drobno posiekanego hiszpańskiego mydła, miarki wody różanej i trzech łyżek psiego sadła. Składniki należało zagotować, a potem formować w kulki (122). Do mycia twarzy można było w domu sporządzić tonik z garści czystej trawy, kwiatu fasoli, kwiatu rozmarynu, kwiatu czarnego bzu, uncji cynamonu i dwóch miarek wody. Mieszaninę tę należało destylować w piwnicy (123). W piwnicy także można było sporządzić perfumy różane, przez czterdzieści dni macerując płatki róży w soli. Naczynie musiało być zakopane w piwnicy (140).

Po lekturze zeszytu Anny Lindheimer-Textor można stwierdzić, że jako książka kucharska nie wyróżnia się niczym nadzwyczajnym. To, że stała się sławna i przechowywana jest w archiwum, nie jest zasługą jej posiadaczki i współautorki. Gdyby nie wnuk Anny Lindheimer, Johann Wolfgang Goethe, brązowy zeszycik byłby jednym z wielu podobnych, spisanych w tamtych czasach - rękopisem notatek, odzwierciedlających gusty kulinarne mieszczaństwa niemieckiego początku XVIII wieku.

Kuchnia mieszczańska, chociaż ciężka i chwilami wręcz niezdrowa, jednocześnie dysponowała wieloma przepisami na przyrządzenie potraw dietetycznych, lekkostrawnych. Była taka, jak i samo mieszczaństwo: solidna, oszczędna, ale zarazem wykwintna; dobra zarówno dla domowników, jak i gości; silnie naznaczona wpływami regionalnymi, ale też otwarta na nowinki z wielkiego świata. A do tego wszystkiego jeszcze - niemal ponadczasowa, ponieważ wiele potraw, które jadał Goethe (miąższ chleba moczony w mleku, smażony na tłuszczu i posypywany cukrem, marcepan, zupy zaprawiane octem, galaretki malinowe odcedzane przez ściereczkę itp.), jada się w Niemczech tradycyjnie do dziś. 